\title{
Chloride accelerated test: influence of silica fume, water/binder ratio and concrete cover thickness
}

\section{Ensaio acelerado por cloretos: efeito da sílica ativa, relação água/aglomerante e espessura de cobrimento do concreto}

E. PEREIRA a

eduardopereira@uepg.br

A. RESENDE ${ }^{\circ}$

andrearesende.s@gmail.com

M. H. F. DE MEDEIROS c medeiros.ufpr@gmail.com

L. C. MENEGHETTI b

\section{Abstract}

Imeneghetti@gmail.com

In developed countries like the UK, France, Italy and Germany, it is estimated that spending on maintenance and repair is practically the same as investment in new constructions. Therefore, this paper aims to study different ways of interfering in the corrosion kinetic using an accelerated corrosion test - CAIM, that simulates the chloride attack. The three variables are: concrete cover thickness, use of silica fume and the water/ binder ratio. It was found, by analysis of variance of the weight loss of the steel bars and chloride content in the concrete cover thickness, there is significant influence of the three variables. Also, the results indicate that the addition of silica fume is the path to improve the corrosion protection of low water/binder ratio concretes (like 0.4 ) and elevation of the concrete cover thickness is the most effective solution to increase protection of high water/binder ratio concrete (above 0.5).

Keywords: corrosion; CAIM; silica fume, water/binder ratio; concrete cover thickness.

\section{Resumo}

Em países desenvolvidos como os do Reino Unido além da França, Itália e Alemanha, estima-se que o gasto com manutenção e reparo é praticamente igual ao investimento em obras novas. Por este motivo, este trabalho visa estudar o efeito de formas de interferir na cinética da corrosão a partir da aplicação de um ensaio acelerado de corrosão - CAIM, que simula o ataque por cloretos. As três variáveis estudadas são: espessura de cobrimento, uso de sílica ativa e relação água/aglomerante. Foi constatado, pela análise de variância da perda de massa das barras e do teor de cloretos na espessura de cobrimento, que existe influência significativa das três variáveis do estudo. Além disso, os resultados indicam que a adição de sílica ativa é o caminho para melhorar a proteção de concretos de relação água/aglomerante baixa $(\mathrm{a} / \mathrm{agl}=0,40)$ e a elevação do cobrimento é o caminho mais eficiente para aumentar a proteção das armaduras em concretos de relação água/aglomerante elevada (a/agl $=0,50$ e 0,60$)$

Palavras-chave: corrosão; CAIM; silica ativa, relação água/aglomerante; espessura de cobrimento.

\footnotetext{
Universidade Estadual de Ponta Grossa, Ponta Grossa, PR, Brasil 84030-900

Universidade Estadual do Oeste do Paraná, Cascavel, PR, Brasil 85819-110

Universidade Federal do Paraná, Curitiba, PR, Brasil 80060-000
} 


\section{Introduction}

Corrosion of reinforcement steel in concrete is a world-wide problem, resulting in high costs of rehabilitation and repair of these structures [1, 2]. The costs of maintenance and prevention of structures that was affected by corrosion sum $3.5-4 \%$ of the al spending $[3,4]$. The indirect costs are more complex and sometimes cannot be account [5]. In Brazil, the problems with corrosion of reinforced concrete correspond to $3.5 \%$ by year of the Gross National Product (GNP) [6]. About of 66.86 billons of dollar by year are spending with the problem of corrosion, considering a GNP equal to 1.91 trillion of dollars. Andrade \& Fortes [7] believes that $18 \%$ of the spending of the GNP, around 15billions of dollars, is the cost of the civil construction with of reinforced concrete corrosion. The steel corrosion of the reinforced concrete is affected by many factors like the concrete properties, time of exposure, steel rebar superficial condition, environmental conditions which the structure are exposed and the use of supplementary cementitious materials. The corrosion rate of reinforcement is strongly influenced by the concrete compressive strength. Ismail \& Ohtsu [8] verified that the corrosion rate for concretes with normal strength are highest than concretes with high strength, that fact is correlated by the water/binder ratio and the presence of the silica fume. Results of the accelerated corrosion tests of concrete with different strength performed by Abosrra et al. [9] confirm the conclusion of the first authors, adding the premise that the corrosion rate increase with the time of exposure.

According Xu et al. [10] the partial replacements of cement by fly ash and silica fume are effective to delay the time of corrosion initiation. Beyond that, although the pozzolanic reaction owing to the addition of mineral admixtures reduces the content of calcium hydroxide present in the pore solution, threshold of chloride does not reduce.

Yalciner et al. [11] evaluated the concrete cover thickness influence on the bond strength in concrete specimens which were submitted to the accelerated corrosion tests. The degradation was higher in the high strength concrete than in normal strength concrete. The corrosion products were flowing to the surface of the concrete in the specimens with a higher w/c ratio. On the other hand, lower permeability of concretes with $\mathrm{w} / \mathrm{c}$ ratio equal to 0.40 maintained expansive corrosion products around the steel bar, re- sulting in premature cracks due the volumetric expansion. This phenomenon contributes for the reduction of the bond strength in high strength concretes.

For many years the researchers of all word are been develop methods for evaluate the corrosion process. By the way, there is not a consensus about the best and reliable test of corrosion in reinforced concrete [12]. The half-cell potential reading [13], the linear polarization and chloride migration $[14,15,16]$ are some of the methods for the evaluation of corrosion process, but this techniques indicated only the advance of the process, not allowing to mitigate the process in the conception phase.

In the accelerated tests, the corrosion is induced by chloride like the accelerated corrosion test by modify immersion - CAIM (Portuguese acronyms) - that consist at forced penetration of chloride in the concrete prism. This kind of test has been used by researchers because of satisfactory results $[17,18,19]$.

In this context, this article study the influence of the cover thickness like a natural barrier to entry of chloride ions, by the CAIM test, as well the influence of water/binder ratio and silica fume benefits in the mitigation of steel corrosion process. The conclusions of this paper can be used for the prevention the corrosion of reinforced concrete in the design phase.

\section{Experimental program}

The experimental program consisted in to submit concrete specimens with an embedded steel rebar to the accelerated corrosion test for evaluating the efficiency of concrete cover thickness as barrier to chloride ions entrance.

\subsection{Variables analyzed}

The analyzed variables in this research are the water/binder ratio $(0.4 ; 0.5 ; 0.6)$, the concrete cover thickness $(4.0 ; 5.0 ; 6.0 \mathrm{~cm})$ and the use of silica fume. Systematizing, this paper analyzes 18 variables: 3 levels of water/binder $\times 3$ levels of concrete cover thickness $\times 2$ levels of with and without silica fume. Three specimens to each analyzed variable were cast for the accelerated corrosion test, resulting 54 concrete prisms. Beyond that, six cylindrical concrete specimens of $10 \mathrm{~cm} \times 20 \mathrm{~cm}$ size were cast to evaluate the compressive strength at 7 and 28 days, totalizing 36 specimens.

Table 1 - Chemical and physical characterization of high early strength Portland cement

\begin{tabular}{|c|c|c|c|c|c|c|c|c|c|c|}
\hline \multicolumn{11}{|c|}{ Chemical composition } \\
\hline \multicolumn{2}{|c|}{ Ignition loss } & $\mathrm{Al}_{2} \mathrm{O}_{3}$ & $\mathrm{SiO}_{2}$ & $\mathrm{Fe}_{2}$ & $\mathrm{CaO}$ & $\mathrm{MgO}$ & $\mathrm{SO}_{3}$ & Free lime & Total alkalies & Insoluble residue \\
\hline \multicolumn{2}{|l|}{$3.6 \%$} & $3.1 \%$ & $17.8 \%$ & 2.42 & $60.5 \%$ & $4.61 \%$ & $3.38 \%$ & $1.7 \%$ & $0.70 \%$ & $2.2 \%$ \\
\hline \multicolumn{11}{|c|}{ Physical and mechanical properties } \\
\hline \multirow{2}{*}{$\begin{array}{l}\text { Specific } \\
\text { gravity }\end{array}$} & \multirow{2}{*}{\multicolumn{2}{|c|}{ Expansion }} & Setting $t$ & & \multirow{2}{*}{$\begin{array}{l}\text { Standard } \\
\text { consistency }\end{array}$} & \multirow{2}{*}{\multicolumn{2}{|c|}{$\begin{array}{c}\text { Blaine's } \\
\text { specific } \\
\text { surface area }\end{array}$}} & Residue on & \multicolumn{2}{|c|}{ Compressive strength of mortar } \\
\hline & & & $\begin{array}{l}\text { Inicial } \mathbf{F} \\
\text { set }\end{array}$ & $\begin{array}{l}\text { Final } \\
\text { set }\end{array}$ & & & & \# $200 \quad \# 325$ & 1 day 3 days & s 7 days 28 days \\
\hline $2.83 \mathrm{~g} / \mathrm{cm}^{3}$ & 0.47 & $\mathrm{~nm}$ & $\begin{array}{c}191 \\
\text { h:min }\end{array}$ & $\begin{array}{l}259 \\
\text { h:min }\end{array}$ & $29.4 \%$ & $484 \mathrm{C}$ & $\mathrm{m}^{2} / \mathrm{g}$ & $0.2 \% \quad 2.0 \%$ & $23.0 \mathrm{MPa} \quad 32.9 \mathrm{MPo}$ & a $\quad 37.8 \mathrm{MPa} \quad 46.3 \mathrm{MPa}$ \\
\hline
\end{tabular}




\section{Table 2 - Characterization of fine and coarse aggregates}

\begin{tabular}{ccccccccc} 
Aggregate & $\begin{array}{c}\text { Pulverulent } \\
\text { materials } \\
\text { content } \\
\%\end{array}$ & $\begin{array}{c}\text { Maximum } \\
\text { size } \\
\mathrm{mm}\end{array}$ & $\begin{array}{c}\text { Fineness } \\
\text { modulus }\end{array}$ & $\begin{array}{c}\text { Swelling } \\
\%\end{array}$ & $\begin{array}{c}\text { Specific gravity } \\
\text { Dry } \\
\text { Saturated } \\
\mathrm{g} / \mathrm{cm}^{3}\end{array}$ & $\begin{array}{c}\text { Bulk density } \\
\text { Loose } \\
\text { Compacted } \\
\mathrm{kg} / \mathrm{dm}^{3}\end{array}$ \\
Fine & 1.1 & 2.40 & 1.74 & 1.37 & 2.65 & 2.68 & 1.58 & 1.78 \\
Coarse & 0.49 & 19.5 & 7.0 & - & 3.01 & 3.02 & 1.66 & 2.24 \\
\hline
\end{tabular}

\subsection{Materials}

Materials were choosing according to the availability on the west of Paraná state. Fine aggregated (a sand of Paraná River) and a basaltic coarse aggregated were used in this experiment. The cement used was the CPV - ARI - RS because is the cement which has the lowest mineral admixture quantity on its composition. Tables 1,2 and 3 shows the principal characteristics of the materials used.

Chemical composition of silica fume is presented in Table 4 and its density is equal to $2.19 \mathrm{~g} / \mathrm{cm}^{3}$. The Muraplast FK22 superplasticizer was used in the proportion recommended by the manufacturer, namely, $0.2-0.3 \%$ of cement mass. Steel rebars $12.5 \mathrm{~mm}$ in diameter and $14.5 \mathrm{~cm}$ long (CA-50A) supplied by Arcelor Mital CA-50 were used in all specimens.

Mixture proportions were defined using the IPT/EPUSP method which is known as four quadrant method. This method is based on the adjustment of strength and workability curves taking account the structural requirements. Mixture proportions of concrete are given in Table 5 along with properties of fresh concrete. For studying the influence of silica fume, the cement mass was partially replaced by silica fume at $8 \%$ of its mass and the water/binder ratio was fixed. In the concrete proportion with water/binder ratio equal to 0.4 was added $0.2 \%$ of superplasticizer.

\subsection{Specimens}

Prismatic concrete specimens of dimension $10 \mathrm{~cm} \times 10 \mathrm{~cm} \times 20$ $\mathrm{cm}$ were cast with an embedded steel bar of $14.5 \mathrm{~cm}$ of length for corrosion accelerate test. The steel bars were fixed according the concrete cover thickness analyzed as show in Figure 1.

According with the accelerated test used the chlorides present on a saline solution was induced by electricity to penetrate into the concrete and to corrode the steel. For this, copper wires were positioned over the bar before casting the specimens (Figure 1b). The wire thickness was $4 \mathrm{~mm}$ which proves to sustain the corrosion on a preliminary test.

Table 3 - Particle size distribution of aggregates

\begin{tabular}{|c|c|c|c|c|c|c|c|}
\hline \multicolumn{4}{|c|}{ Coarse aggregate } & \multicolumn{4}{|c|}{ Fine aggregate } \\
\hline \multirow{2}{*}{$\begin{array}{l}\text { Sieve size } \\
(\mathrm{mm})\end{array}$} & \multirow{2}{*}{$\begin{array}{l}\text { Mass } \\
\text { retained (g) }\end{array}$} & \multicolumn{2}{|c|}{ Percentage (\%) } & \multirow{2}{*}{$\begin{array}{l}\text { Sieve size } \\
(\mathrm{mm})\end{array}$} & \multirow{2}{*}{$\begin{array}{l}\text { Mass } \\
\text { retained (g) }\end{array}$} & \multicolumn{2}{|c|}{ Percentage (\%) } \\
\hline & & Retained & Cumulative & & & Retained & Cumulative \\
\hline 37.5 & - & 0 & 0 & 6.3 & 0.8 & 0.13 & 0 \\
\hline 31.5 & - & 0 & 0 & 4.75 & 0.6 & 0.1 & 0 \\
\hline 25 & - & 0 & 0 & 2.36 & 3.8 & 0.63 & 1 \\
\hline 19.5 & 57 & 5.7 & 6 & 1.2 & 33 & 5.41 & 6 \\
\hline 12.5 & 604.2 & 60.5 & 66 & 0.6 & 39.3 & 6.44 & 13 \\
\hline 9.5 & 283.5 & 28.4 & 95 & 0.3 & 225.1 & 36.87 & 50 \\
\hline 4.75 & 47.3 & 4.7 & 99 & 0.15 & 270.8 & 44.36 & 94 \\
\hline$<4.75$ & 6.8 & 0.7 & 100 & $<0.15$ & 37 & 6.06 & 100 \\
\hline Total & 998.8 & 100 & - & Total & 610.4 & 100 & - \\
\hline
\end{tabular}

Table 4 - Chemical characterization of silica fume

\begin{tabular}{cccccccccccccc|}
\hline 10 & \multicolumn{11}{c|}{ Chemical composition (\%) } \\
$\mathrm{SiO}_{2}$ & $\mathrm{~K}_{2} \mathrm{O}$ & $\mathrm{Fe}_{2} \mathrm{O}_{3}$ & $\mathrm{CaO}$ & $\mathrm{Al}_{2} \mathrm{O}_{3}$ & $\mathrm{P}_{2} \mathrm{O}_{5}$ & $\mathrm{TiO}_{2}$ & $\mathrm{SO}_{3}$ & $\mathrm{MgO}$ & $\mathrm{Cl}$ & $\mathrm{ZnO}$ & $\mathrm{MnO}$ & $\mathrm{Na}_{2} \mathrm{O}$ & $\mathrm{BaO}$ \\
\hline 96.4 & 0.94 & 0.06 & 0.3 & 0.02 & 0.11 & 0.007 & - & 0.73 & - & - & 0.029 & 0.17 & - \\
\hline
\end{tabular}


Table 5 - Material consumption per $\mathrm{m}^{3}$ of concrete and slump

\begin{tabular}{ccccccc}
$\begin{array}{c}\text { Concrete } \\
\mathrm{mix}\end{array}$ & $\begin{array}{c}\text { Cement } \\
\left(\mathrm{kg} / \mathrm{m}^{3}\right)\end{array}$ & $\begin{array}{c}\text { Silica fume } \\
\left(\mathrm{kg} / \mathrm{m}^{3}\right)\end{array}$ & $\begin{array}{c}\text { Fine aggregate } \\
\left(\mathrm{kg} / \mathrm{m}^{3}\right)\end{array}$ & $\begin{array}{c}\text { Coarse aggregate } \\
\left(\mathrm{kg} / \mathrm{m}^{3}\right)\end{array}$ & $\begin{array}{c}\text { Water } \\
\left(\mathrm{kg} / \mathrm{m}^{3}\right)\end{array}$ & $\begin{array}{c}\text { Slump } \\
(\mathrm{mm})\end{array}$ \\
\hline 1 & 510.46 & - & 689.12 & 1107.70 & 204.18 & 90 \\
2 & 384.32 & - & 518.83 & 833.97 & 192.16 & 110 \\
3 & 303.69 & - & 409.98 & 659.01 & 182.21 & 110 \\
4 & 469.62 & 40.84 & 633.99 & 1019.08 & 187.85 & 90 \\
5 & 353.57 & 30.75 & 477.33 & 767.26 & 176.79 & 100 \\
6 & 279.39 & 24.30 & 377.18 & 606.29 & 167.64 & 110 \\
\hline
\end{tabular}

After casting for $24 \mathrm{~h}$, all concrete specimens were removed from the moulds and then cured under saturated condition during 28 days. After that, the specimens were submitted to the accelerated corrosion test by modified immersion.

\subsection{Accelerated corrosion test by modified immersion - CAIM}

The accelerated corrosion test by modified immersion - CAIM are an electrochemical test that was developed by researchers at Federal University of Rio Grande do Sul (UFRGS). The original conception was developed by Varela, Espinosa [20], and was first used by Lima [17], after that several researchers have been using the CAIM test $[18,19]$. Given its characteristics, can be efficiently used to obtain comparative data for corrosion protection [18].

The corrosion on this test is induced by an electrochemical way that matches the exposure of the specimens on aggressive solutions with the electric current to stimulate the chlorides migration. In this test, the concrete specimens were immersed in an aqueous solution of $35 \mathrm{~g} / \mathrm{l}$ of $\mathrm{NaCl}$ which is similar to the Atlantic Ocean [19]. This concentration helps the migration of the oxygen and chloride into the concrete specimens. An adjustable direct current supply was used for the accelerated corrosion process as shown in Figure 2.
The tests simulate the basic condition for corrosion starts but with an accelerated speed. When the CAIM test was used to accelerate the corrosion process the answers of the corrosion are given by the oxide and iron hydroxide formation on the surface of the steel bar that causes the longitudinal cracking. The result of CAIM allows inferring relatively the quality of concrete [19].

An accelerated corrosion chamber was constructed before start the tests. The chamber was projected to provide a saline internal environment without change fluids with the external environment and was made using marine plywood covered with glass plate which allows monitor visually the tests. The dimensions are $90 \mathrm{~cm} \times 200 \mathrm{~cm}$ $x 40 \mathrm{~cm}$ which allow test several specimens simultaneously.

The specimens were partially immersed in individual recipients without solution renewal during the tests. The height of solution was defined according with the concrete cover thickness of the steel bar.

On the beginning of test the copper wire was connected with steel bar and the positive pole of the power supply - acting as the anode of electrochemical process. Other copper wire, without overlay was putted on the solution of $\mathrm{NaCl}$ and connected with the negative pole of the power supply - acting as the cathode of the process. The current intensity set was of $500 \mu \mathrm{A} / \mathrm{cm}^{2}$ what corresponds to approximately $24.8 \mathrm{~mA}$.

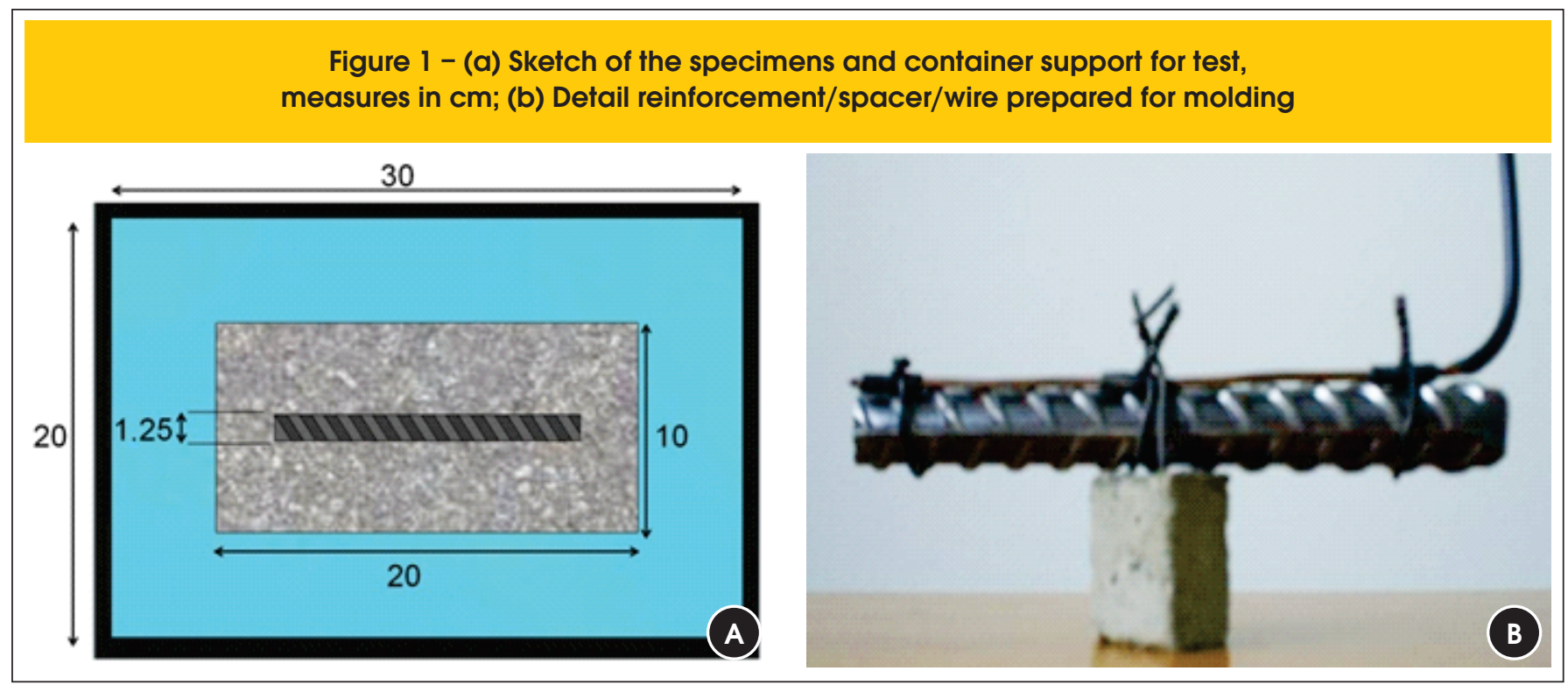




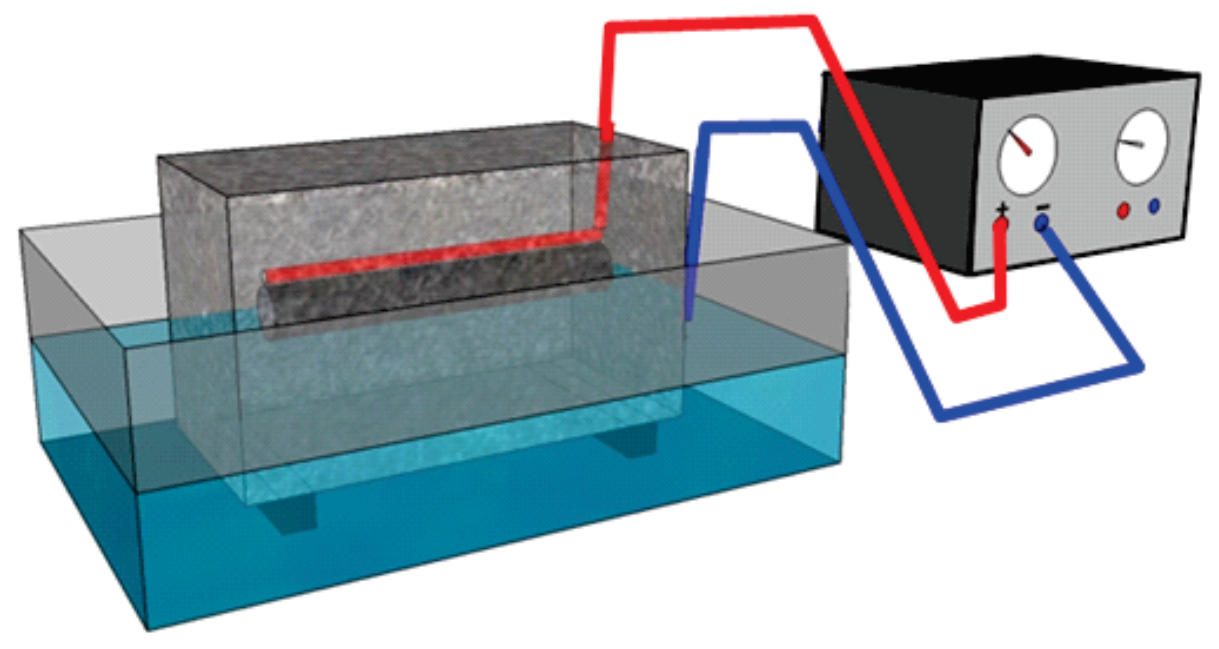

A Dawer PS - 3003 D power supply was used to apply the current, besides of a nobreak system to provide the energy in an emergency case. In the laboratory, the temperature was held at $23^{\circ} \mathrm{C}$ and $60 \%$ humidity, but inside the chamber this parameters was not controlled.

An electrical circuit holding the specimens and the power supply was created in order to test many specimens at same time. This option that uses an electric circuit was used regarding the electrical rules of series resistor associations where the electric current keeps the same for all resistors. The number of specimens (maximum 3 ) that was held in a series circuit was determined by the maximum potential range which was support by the power supply keeping the electric current defined for this work.

The specimens were submitted to the CAIM test during 20 days. After that the concrete specimens were maintained in environment temperature to dry by 7 days. Following the specimens were examined visually for degradation condition and to extract the concrete dust to measure the chloride content. The dust extraction was performed with a bench drill with a scale to ensure the concrete cover thickness.

The dust samples were sealed in plastic bags and transported to the Concrete Laboratory of Itaipu Hydroelectric Plant to analyze the chloride content. After the dust extraction the concrete speci- mens were ruptured to remove the steel bar. The steel bars were cleaned as described in ASTM A380 [21] and then weighted.

\section{Results and discussions}

The main response variables analyzed in this paper were the steel bar weight loss and the percentage of chloride on the thickness cover of a concrete prism after an accelerated corrosion test, and the compressive strength of the concrete. The results of compressive strength are shown in Table 6 and were used as the characterizing parameter for the concretes in the study.

\subsection{Degree of corrosion measured through the weight loss of the steel bar}

The data obtained from the experimental program were first statistically treated in order to identify and eliminate outliers. The data were considered spurious when the absolute value of the response variable subtracted from the average of its repetitions was greater than their standard deviation. Those values were discarded and the average was recalculated without the use of the discarded values Figure 3 shows average values of weight loss (corrosion rate) for the three variables. The graph allows a better visualization of the studied variables Behavior.

Table 6 - Compressive strength of concrete (MPa)

\begin{tabular}{|c|c|c|c|c|c|c|c|}
\hline & & \multicolumn{6}{|c|}{ Water/binder ratio } \\
\hline & & \multicolumn{3}{|c|}{ without silica fume } & \multicolumn{3}{|c|}{ with silica fume } \\
\hline \multirow{3}{*}{ Day } & & 0.4 & 0.5 & 0.6 & 0.4 & 0.5 & 0.6 \\
\hline & 7 & 38.9 & 28.0 & 24.5 & 39.4 & 32.8 & 23.8 \\
\hline & 28 & 47.2 & 38.2 & 31.2 & 49.6 & 36.9 & 31.7 \\
\hline
\end{tabular}




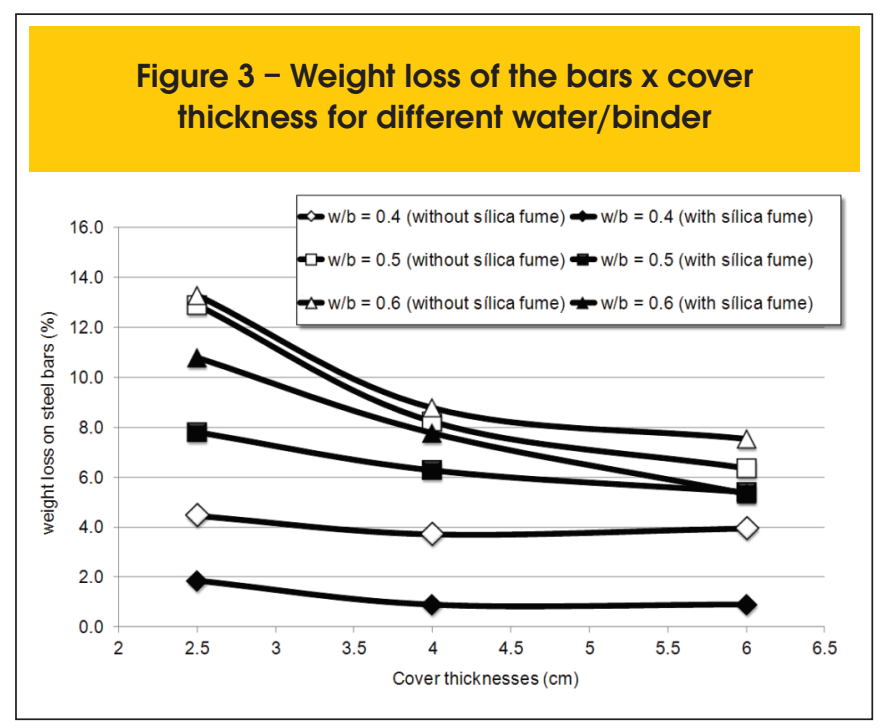

Analyzing Figure 3 it is possible to see the influence of the water/ binder ratio, the addition of silica fume and the thickness of coatings in the weight loss of steel bars subjected to corrosion process. The result shows that these parameters have a strong influence on the ability to protect the steel within the concrete, which can be used as a tool to adapt the structure to the level of durability expected in the projects.

After elimination of the spurious values, the verification of the variables influence in the corrosion process was made by a variance analysis (ANOVA) on the data of weight loss of bars inserted in the specimens of concrete, with a significance level of $95 \%$. A summary of results is described in Table 7 and the interpretation is made in a way that the analysis factor is considered to be influent with a $95 \%$ significance.

\subsection{Influence of water/binder ratio}

The results of weight loss as a function of the water/binder ratio confirm the expectation that the water/binder ratio has significant influence on the corrosion of steel. Figure 3 shows the increase in weight loss of the steel bars with the increase of the water/binder ratio for the series without silica fume, indicating that changes in this variable implicate in significant changes in the weight loss of carbon steel bars embedded in the bodies of proof tested with CAIM.

This behavior is due to the fact that the lower the amount of water in the mixture is, the greater protection will be granted to the concrete when exposed to the weather, due to the reduction in pore size and consequent difficulty of penetration by fluids and aggressive agents. This relationship is well known in the scientific and technical fields and has been proven from studies as follows: Lafhaj et al. [22] show that the higher the water/binder ratio is, the greater the total porosity of the cementitious material will be. Hedenblad [23] paper indicates that the greater the total porosity of the cementitious material is the greater permeability it will have. The degree of cement hydration and its porosity increased with the increase in water/cement ratio. This was verified in the study of Chen, Wu [24] in mortars with mix proportion of $1: 2$ by weight and it was demonstrated that for a water/cement ratio of 0.4 the

\section{Table 7 - Analysis of variance ( $95 \%$ significance): influence of the water/binder, cover thickness and presence of silica fume in concrete}

\begin{tabular}{|c|c|c|c|c|c|c|c|}
\hline \multicolumn{2}{|c|}{ Water/binder ratio } & $\begin{array}{l}\text { Sum of } \\
\text { squares }\end{array}$ & $\begin{array}{l}\text { Degrees of } \\
\text { freedom }\end{array}$ & $\begin{array}{l}\text { Mean } \\
\text { square }\end{array}$ & F-score & $\begin{array}{c}\text { Tail } \\
\text { probability }\end{array}$ & Effect \\
\hline \multirow{3}{*}{$\begin{array}{l}\text { Without } \\
\text { silica } \\
\text { fume }\end{array}$} & Cover thickness $=2.5$ & 155.9438 & 2 & 77.97192 & 69.19545 & 5.143253 & Significant \\
\hline & Cover thickness $=4.0$ & 60.1316 & 2 & 30.0658 & 20.56927 & 5.143253 & Significant \\
\hline & Cover thickness $=6.0$ & 22.9483 & 2 & 11.47417 & 72.30734 & 5.143253 & Significant \\
\hline \multirow{3}{*}{$\begin{array}{l}\text { With } \\
\text { silica } \\
\text { fume }\end{array}$} & Cover thickness $=2.5$ & 169.8875 & 2 & 84.94375 & 30.85882 & 5.143253 & Significant \\
\hline & Cover thickness $=4.0$ & 77.15959 & 2 & 38.5798 & 6.873874 & 5.143253 & Significant \\
\hline & Cover thickness $=6.0$ & 42.5409 & 2 & 21.27047 & 45.53911 & 5.143253 & Significant \\
\hline \multicolumn{2}{|c|}{ Cover thicknesses } & $\begin{array}{l}\text { Sum of } \\
\text { squares }\end{array}$ & $\begin{array}{l}\text { Degrees of } \\
\text { freedom }\end{array}$ & $\begin{array}{l}\text { Mean } \\
\text { square }\end{array}$ & F-score & $\begin{array}{c}\text { Tail } \\
\text { probability }\end{array}$ & Effect \\
\hline \multirow{3}{*}{$\begin{array}{l}\text { Without } \\
\text { silica } \\
\text { fume }\end{array}$} & water $/$ binder $=0.4$ & 2.273218 & 2 & 1.136609 & 0.653028 & 5.143253 & Non-significant \\
\hline & water/binder $=0.5$ & 67.08003 & 2 & 33.54001 & 180.9271 & 5.143253 & Significant \\
\hline & water/binder $=0.6$ & 45.02897 & 2 & 22.51449 & 27.413 & 5.143253 & Significant \\
\hline \multicolumn{2}{|c|}{ With silica fume } & $\begin{array}{l}\text { Sum of } \\
\text { squares }\end{array}$ & $\begin{array}{l}\text { Degrees of } \\
\text { freedom }\end{array}$ & $\begin{array}{l}\text { Mean } \\
\text { square }\end{array}$ & F-score & $\begin{array}{c}\text { Tail } \\
\text { probability }\end{array}$ & Effect \\
\hline \multirow{3}{*}{$\begin{array}{c}\text { Different } \\
\text { thicknesses }\end{array}$} & water $/$ binder $=0.4$ & 21.61406 & 1 & 21.61406 & 24.13078 & 4.49400 & Significant \\
\hline & water $/$ binder $=0.5$ & 25.48186 & 1 & 25.48186 & 4.63315 & 4.49400 & Significant \\
\hline & water $/$ binder $=0.6$ & 3.24498 & 1 & 3.24498 & 0.31205 & 4.49400 & Non-significant \\
\hline
\end{tabular}




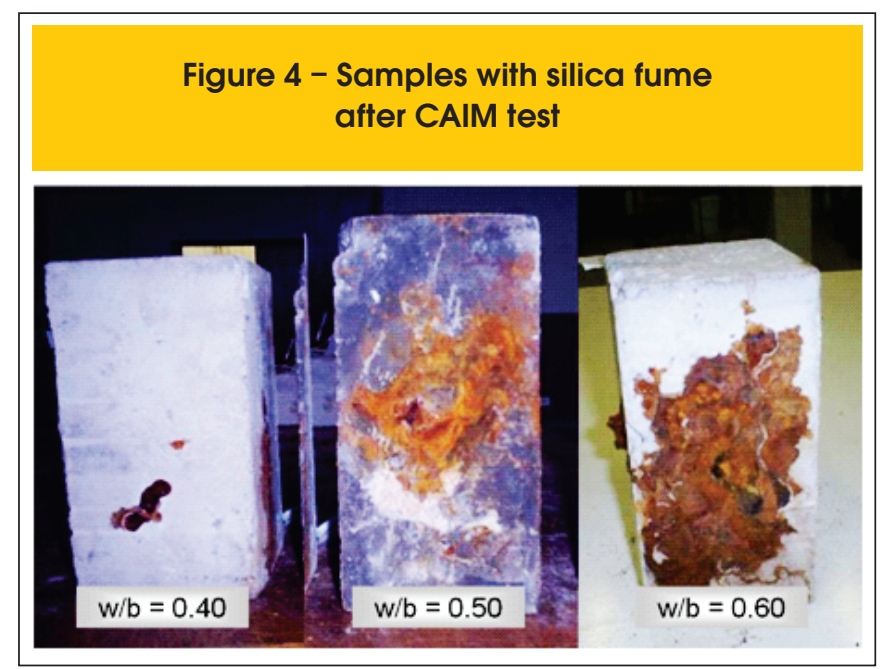

degree of hydration was $68 \%$ and for a water/cement ratio of 0.6 the degree of hydration was $81 \%$, both at 180 days of healing. However, the study also indicated that the mortar with high water/ cement ratio has a range of large pores not present in mortar with a low water/cement ratio. This information coincides with the classic results shown in Powers studies [25].

Note that weight losses of the steel bars are most pronounced when changing the water/binder ratio from 0.4 to 0.5 than from 0.5 to 0.6 . This demonstrates a tendency to produce more durable concrete water/binder relations below 0.5 will be used. The NBR 6118 [26] allows the use of water/binder ratios equal to 0.5 for the class III of aggressiveness (industrial atmosphere or sea), this recommendation would be considered lax if these results had been obtained in the field and not in accelerated testing. Thus, this result serves as a warning, but it is necessary to perform accelerated experiments to better substantiate these preliminary findings. This view is based on the fact that the accelerated degradation does not fully reproduce the actual exposure conditions of a structure in the environment near the ocean.

Visual analysis of the specimens after the CAIM essay allows checking the aesthetic effects that the corrosion process causes on the concrete. Figure 4 shows the state of degradation observed in the specimens with the three water/binder ratios studied for a concrete cover thickness of $4.0 \mathrm{~cm}$ in the presence of silica fume. The corrosion process installed generates the formation of corrosion products, which due to abundant moisture during the test, generates spots in the surface of the specimens. It is possible to associate the occurrence intensity of those spots in the surface with the quality of the concrete used. It is possible to see in Figure 4 that the lower the water/binder ratio is, the less apparent effects of corrosion on the surface of the concrete are, thus confirming the conclusions above.

\subsection{Influence of the cover thickness}

The cover thickness in concrete is a very important factor to control the movement of chloride ions and penetration of substances harmful to the concrete. It plays the role of physical protection, because it hinders the entry of aggressive agents, oxygen and moisture, as well as ensuring the alkaline medium so that the reinforce- ment has a chemical protection. Figure 3 shows the influence of different thicknesses as a protective barrier to the steel of concrete without silica fume.

In theory, for concretes with similar quality, the greater the cover thickness is, the greater tends to be the time interval until the chloride concentration near the steel reaches the threshold value, since the thickness tends to work like a barrier to ions penetration. As the specimens were exposed to the test during the same time period, this claim can be confirmed by looking at Figure 3, where the concrete cover decreases, there is an increase in the weight loss of the steel bars in concrete for a water/binder ratio of 0.5 and 0.6 . In mixtures with water/binder ratio equal to 0.40 , there seems to be no change in weight loss for different thicknesses of reinforcement or at least, this effect is much smaller. It is assumed that for this water/binder ratio, the microstructure of the concrete is so dense that it becomes the predominant factor on the rate of ions penetration, like indicated by studies of Medeiros, Helene [27] and Chen, Wu [24].

The NBR 6118 [26] recommended as limits for Class IV aggressiveness a cover thickness of $5.0 \mathrm{~cm}$ and water/binder ratio of 0.45 . According to results obtained in this research, there is no need to use floor coverings larger than $4.0 \mathrm{~cm}$ because of the concrete microstructure. This statement was confirmed by variance analysis with $95 \%$ significance according to Table 7 , indicating that the variation in cover thickness (between 2.5 and $6 \mathrm{~cm}$ ) is not significant in the case of a water/binder ratio equal 0.4 and is significant in the case of water/binder ratios of 0.5 and 0.6 .

It is important to note that this interpretation is based strictly on the materials used and the exposure conditions imposed in this test. The actual exposure of a concrete structure has numerous influencing factors that were not simulated in the test employed and, therefore, the NBR 6118 should continue to be followed.

Through visual analysis, an effect observed in all specimens with concrete cover thickness equal to $6.0 \mathrm{~cm}$ is the appearance of cracks due to the expansive nature of the products originated by corrosion (Figure 5). This phenomenon is attributed to the excessive coatings used since samples of the bottom did not showed such occurrence.

It can be concluded, based on the information and on previous analyzes, that the higher the thickness is, the lower will be the

\section{Figure 5 - Cracking in samples without silica fume caused by excessive cover thickness (cover thickness $=6.0 \mathrm{~cm}$ )}

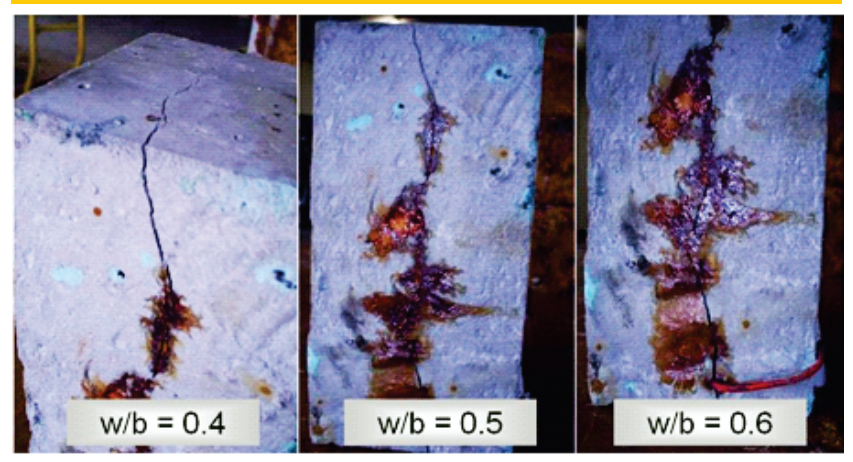


weight loss of the reinforcement, but when the ratio water/binder decreases to values close to 0.40 , the pores of concrete tend to be so dense that they alone protect against the corrosive process not requiring an excessive thickness, which in this case could even be harmful to the concrete. A detailed study of the concrete porosity could support this analysis.

\subsection{Influence of silica fume presence}

The use of silica fume in concrete caused a decrease in weight loss of the steel bar inserted into the concrete prism. This decrease is attributed to the possibility of this pozzolan filling the voids present inside the material (the filler effect associated with pozolanic reactions), making the material more resistant to the entry of chloride. Nevertheless, it is observed that the higher the water/binder ratio is, the less significant this effect is too, up to the point where the presence of this addition shall not influence the weight loss of bars inserted in concrete with water/binder ratio equal to 0.6. The interpretation of data makes one to believe that the use of silica fume in the dosage of concrete is more advantageous when working with specific low water/binder ratios.

The concrete with silica fume had a compressive strength very similar to the one of concrete without silica fume, however in the case of low water/binder ratio (in this case equal to 0.4 ) there is a capacity to protect the reinforcement from corrosion by chlorides much higher than the specimens without this addition, as shown in Figure 3.

This is an indication that at low water/binder ratios, concrete with silica fume changes the microstructure in order to hinder the penetration of chlorides. This clearly shows that using compressive strength as the sole determining factor for the durability of concrete may lead to erroneous conclusions, and that other parameters are required for a more complete analysis. Ramezanianpour and Malhotra [28] also presents results that reinforce this issue because they compared concrete made with the same water/binder ratio and with Brazilian cement in Brazil equivalent to CP I - 32, with a concrete having $10 \%$ of silica fume as a replacement to cement mortars. The result found indicates maintenance of compressive strength; however, there was a clear reduction in porosity and pore refinement caused by the use of silica fume. Moreover, this percentage of replacement resulted in a considerable increase in resistance to penetration of chloride ions, due to the reduction of porosity.

This was attributed by the authors to the effect of pozolanic reactions caused by silica fume. It is noteworthy that Atis et al. [29] showed in their experiment that the concrete with silica fume is more likely to have its resistance affected by dry curing, or by the lack of healing that occurs in many works. Meloleepszy and Deja [30] also showed similar results studying the replacement percentage of $5 \%$ to $10 \%$ of silica fume with a reduction of up to $40 \%$ in compressive strength results. Thus, one should be alert to this issue: apparently silica fume produces a concrete that better blocks aggressive agents, however, the wet curing has a more important role than in the case of conventional concrete.

\subsection{Concentration of chlorides in concrete cover thickness}

The accelerated test distorts environmental conditions and cannot serve as a fixed parameter for comparison with data obtained from tests performed naturally, however, it serves as a basis for understanding the variables that influence the process and so measures can be taken to mitigate the pathological manifestations from reinforcement corrosion. There is, however, a large movement from researchers to try to correlate the data obtained with accelerated tests and the degradation observed in structures exposed to the environment.

In the accelerated corrosion essay modified by immersion (CAIM), the electric current applied to the specimens induces the migration of chlorides present in the solution toward the steel bar inside the specimen. As a result, the chlorides become lodged in the pores of the concrete. In this work, the concentration of chlorides present in cover thickness of concrete subjected to CAIM testing was evaluated. The counting of chloride in the powder extracted from the concrete cover was performed using Volhard's method as described by Andrade [31]. The ASTM C1152-04 [16] references titration with silver nitrate for determination of chloride ions in samples of cement and concrete using procedures similar to those used by Andrade [31]. On the data of chloride percentage was applied the same preliminary treatment used to refine the data of weight loss by corrosion. The data obtained after the preliminary treatment are shown in Figure 6.

Figure 6 shows the behavior of chloride content for all variables of this study. It is observed that all the curves show the same trend observed for the weight loss of steel bars, which confirms the conclusions about the influence of the variables across the deposition of chlorides in concrete.

Note that almost all specimens are with their levels of chlorides above that one proposed by Helene [12] of $0.05 \%$ to $0.1 \%$ relative to the mass of concrete that according the author is the range of average values more accepted among researchers as the critical corrosion limit. The Euro-International Committee for Concrete (CEB, 1992) recommends that the chloride content in concrete should not exceed $0.05 \%$ in relation to the mass of concrete. Looking at Figure 6 it is possible to confirm the hypothesis that the weight loss of the bar deteriorated through the corrosion process by chloride is directly related to the concentration of chlorides on the concrete cover thickness. The results demonstrate a potential

Figure 6 - Chloride content in the cover thickness region, extracted from samples after the CAIM test

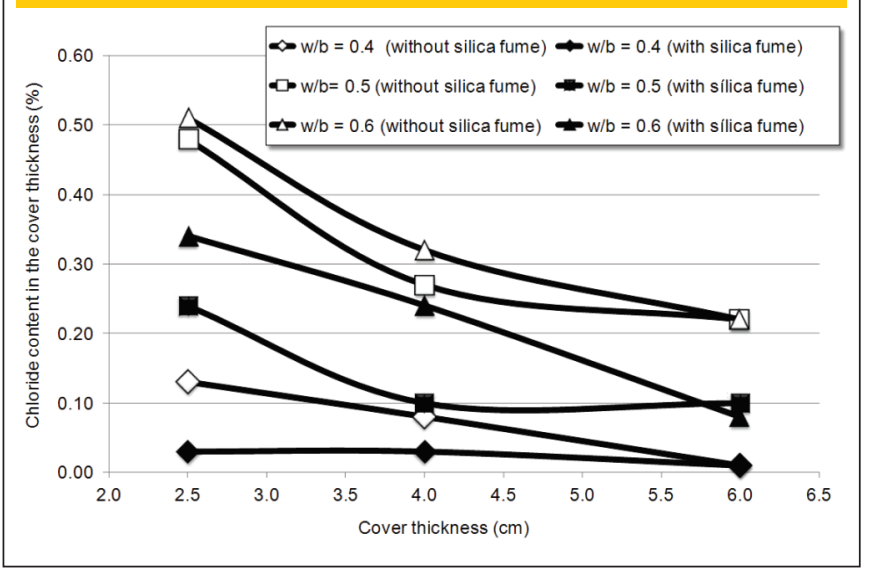


for studies about the interpretation of the data obtained from the CAIM test from the viewpoint of chloride percentage, since the behavior of the curves is similar. With this approach, one can associate more readily results obtained in laboratory with tests performed on the environment, since for obtaining analysis data of chlorides it is only needed to read the content of ions during the time of measurement, without requiring historical data, different from the weight loss test, in which the initial weight of the bars must have been recorded. Furthermore, the use of chloride percentage as the response variable allows each test specimen to be monitored throughout the test, since it is possible to perform extractions in a part of the specimen, filling the holes collection sample punctually with epoxy and continuing with the exposition. In the case of weight loss, only one reading is possible, because the bar needs to be extracted from the specimens to obtain the final result.

All accelerated test distorts the aggressive conditions, which makes it difficult to correlate testing conditions to natural conditions, and virtually impossible to estimate lifetime from analysis of tests times. Nevertheless, CAIM essays may be useful for comparative analyzes that seek to identify how changes in materials affect the corrosion process and how degradation effects evolve. The information presented in this paper make it clear that the current standards (national and international) still use methods based on previous experiences with the prescription of coating thickness, cement consumption and minimum strength for each type of exposure condition. To introduce deterministic methods in standards constitutes a major challenge for civil engineering making lifetime analysis more precise, versatile and reliable. This is a challenge due to the higher difficulty of control and specification, but that would make the technology of reinforced concrete structures more consistent, since it would open up the possibility of using, for example, a $50 \mathrm{MPa}$ concrete and adopt a cover thickness less than the one to be used if the same structure was performed with a 25 MPa concrete.

Currently, the standards prescribe a minimum resistance and cover thickness ignoring that the quality of the concrete cover thickness can be very different between concretes. To get to the point of applying the reasoning embedded in deterministic methods, works to quantify the influence of parameters such as thickness and quality of the cover thickness, use of admixtures, compactness and other factors that influence the protection of the steel are needed.

\section{Conclusion}

The experimental program of this paper allows the following conclusions:

- The CAIM method was satisfactory and is a technique with great potential for use in comparative data of materials considering durability, it is a quick way to make comparisons and choosing building materials;

- The three variables (cover thickness, the use of silica fume and the water/binder ratio) had influence on the corrosion process. This was evidenced by the weight loss of steel bars after CAIM method and the percentage of chloride in the concrete cover thickness;

- The water/binder ratio proved to be the most important factor controlling the movement of chloride ions. This effect is attributed to the porosity of concrete, because the lower the water/ binder ratio is lesser the mass loss of the steel bars and the lower percentage of chloride;
- The greater the cover thickness smaller will be the mass loss of reinforcement. However, the data show that this increase is small for the water/binder ratio of 0.4 and very significant for values of water/binder ratio like 0.5 and 0.6 . In general, the use of low values of cover thickness $(2.5 \mathrm{~cm})$ was inefficient, considering the high degree of loss of mass of reinforcement, thus confirming the recommendations of the various standards;

- The addition of silica fume in concrete provided a decrease in weight loss bars, and the loss level is proportional to the water/ binder ratio. The use of silica fume tends to be more advantageous for concrete with lower water/binder rations and little effective for high values of the water/binder ratios;

- There is a correlation between the percentage of chloride on concrete cover thickness and mass loss in steel bars, thus demonstrating that the concentration of chloride ions is a determining factor in the process. This finding is a factor to be better studied primarily in an attempt to relate accelerated with in situ tests obtained in inspection works in real structures.

\section{Acknowledgments}

The authors thank the State University of West Paraná-UNIOESTE and Federal University of Paraná - UFPR the partnership in this work. Thanks also to the support of the Centre for Advanced Studies in Dam Safety Itaipu Technological Park (Ceasb / PTI) through scientific initiation scholarship and Technology Laboratory of Concrete Itaipu Hydroelectric Power Plant by performing some tests.

\section{References}

[01] Z, LOUNIS. Reliability-based life prediction of aging concrete bridge decks. National Research Council Canada. NRCC 44246. Proceedings of the International RILEM Workshop on Life Prediction and Aging Management of Concrete Structures, Cannes, France, 2000.

[02] O. T, RINCÓN; Duracon Collaboration. Durability of concrete structures: DURACON, an iberoamerican project. Preliminary results. Building and environment. Volume 41. pp. 952-962. 2006.

[03] R, BABOIAN. Corrosion - a problem of international importance. In: ASTM STP 1000. Corrosion testing and evaluation: Silver anniversary volume. Philadelphia. 1990. P, 7-13.

[04] W, D. CALLISTER. Ciência e engenharia dos materiais: uma introdução. Trad. Sérgio Murilo Stamile Soares. 5. ed. Rio de Janeiro: LTC, 2000.

[05] E. C. B, MONTEIRO. Avaliação do método de extração eletroquímica de cloretos para reabilitação de estruturas de concreto com problemas de corrosão. Tese (Doutorado). Escola Politecnica da Universidade de São Paulo. São Paulo, 2002.

[06] J. M. R, DOTTO. Corrosão do aço induzida por íons cloretos - uma análise crítica das técnicas eletroquímicas aplicadas ao sistema aço-concreto com e sem pozolana. 2006. Tese (Doutorado em engenharia civil) - Programa de pos graduação em engenharia civil: PPGEC/UFRGS, Porto Alegre, 2006. 
[07] J. C, ANDRADE; R. L, FORTES. Corrosão na Armadura do Concreto Armado: Influência dos Agentes Cloretos e da Carbonatação. Engenharia, Fortaleza, v. 13, p. 85-96, 1995.

[08] M. ISMAIL; M. OHTSU. Corrosion rate of ordinary and high-performance concrete subjected to chloride attack by $\mathrm{AC}$ impedance spectroscopy. Construction and Building Materials. V. 20. pp. 458-469. 2006.

[09] L. ABOSRRA; A. F. ASHOUR; M. YOUSEFFI. Corrosion of steel reinforcement in concrete of different compressive strengths. Construction and Building Materials. v. 25. pp. 3915-3925. 2011.

[10] J. XU; L. JIANG; W. WANG; Y. XU; Y. JIANG. Chloride threshold value for reinforcement corrosion in concrete with additions of silica fume or fly ash. Magazine of Concrete Research. v. 63, pp. 905-913. 2011

[11] H. YALCINER, O. EREN, S. SENSOY. An experimental study on the bond strength between reinforcement bars and concrete as a function of concrete cover, strength and corrosion level. Cement and Concrete Research. v. 42. pp. 643-655. 2012.

[12] P. R. L, HELENE. Vida útil de estruturas de concreto armado sob o ponto de vista da corrosão da armadura. In: Seminário de dosagem e controle dos concretos estruturais. Anais ENCOL/SENAI. Brasília, 1993.

[13] AMERICAN SOCIETY FOR TESTING AND MATERIALS (ASTM). Standard test method for half-cell potentials of uncoated reinforcing steel in concrete. ASTM C 876. In: Annual book of ASTM Standards. Philadelphia, 1999.

[14] AMERICAN SOCIETY FOR TESTING AND MATERIALS (ASTM). Standard Test Method for determining the apparent chloride diffusion coefficient of cementitious mixtures by bulk diffusion. ASTM C 1556.. In: Annual book of ASTM Standards. West Conshohocken, 2004.

[15] AMERICAN SOCIETY FOR TESTING AND MATERIALS (ASTM). Standard Test Method for Electrical Indication of Concrete's Ability to Resist Chloride Ion Penetration. ASTM C 1202. In: Annual book of ASTM Standards. West Conshohocken, 2005.

[16] AMERICAN SOCIETY FOR TESTING AND MATERIALS. Standard test methods for acid-soluble choride in mortar and concrete. ASTM C1152. Philadelphia, 2003.

[17] R. C. A, LIMA. Investigação do comportamento de concretos em temperaturas elevadas. Tese (Doutorado em Engenharia Civil) - Programa de Pós Graduação em Engenharia Civil: PPGEC/UFRGS, Porto Alegre, 2005.

[18] A, GRAEFF, A. Avaliação experimental e modelagem dos efeitos estruturais da propagação da corrosão em elementos de concreto. 2007. Dissertação (Mestrado em Engenharia Civil) - Programa de Pós Graduação em Engenharia Civil: PPGEC/UFRGS, Porto Alegre, 2007.

[19] A. S, TORRES. Avaliação da sensibilidade do ensaio CAIM - corrosão acelerado por imersão modificada - frente ao processo de corrosão. 2006. Dissertação (Mestrado em Engenharia Civil) - Programa de Pós Graduação em Engenharia Civil: PPGEC/UFRGS, Porto Alegre, 2006.
[20] VARELA, H; ESPINOZA, L. V. Penetrabilidad de iones cloruors em morteros com y sin revestimento. VII Jornadas Chilenas Del Hormigón e I Jornada Latinoamericana Del cimento y Hormigón. Santiago de Chile. 1988.

[21] AMERICAN SOCIETY FOR TESTING AND MATERIALS. Annual book of ASTM Standards. Standard practice for cleaning, descaling and passivation of stainless steel parts, equipment and systems. (Revision). ASTM A380. Philadelphia, 1996.

[22] Z. LAFHAJ; M. GOUEYGOU; A. DJERBI; M. KACZMAREK. Correlation between porosity, permeability and ultrasonic parameters of mortar with variable water/ cement ratio and water content. Cement and Concrete Research. v. 36. pp. 625-633. 2006.

[23] G. HEDENBLAD. The use of mercury intrusion porosimetry or helium porosity to predict the moisture transport properties of hardened cement paste. Advances in Cement Based Materials. v. 6. pp. 123-129. 1997.

[24] X. CHEN; S. WU. Influence of water-to-cement ratio and curing period on pore structure of cement mortar. Construction and Building Materials. v. 38. pp. 804-812. 2013.

[25] T. C. POWERS. Structure and physical properties of hardened Portland cement paste. Journal of American Ceramic Society. v. 41. n. 1 pp. 1-6. 1958.

[26] ASSOCIAÇÃO BRASILEIRA DE NORMAS TÉCNICAS. Projeto e Execução de Estruturas de Concreto Armado - Procedimento. NBR 6118, Rio de Janeiro, 2007.

[27] M. H. F. MEDEIROS; P. HELENE. Migração de Íons Cloretos no Concreto - Influência da Consistência, Relação Água Cimento e Consumo de Cimento. Revista do IBRACON - Instituto Brasileiro do Concreto, São Paulo - Brasil, v. Fev/Ma, p. 53-66, 2003.

[28] A. A. RAMEZANIANPOUR; V. M. MALHOTRA. Effect of curing on the compressive strength, resistence to chloride-ion penetration and porosity of concretes incorporating slag, fly ash or sílica fume. Cement and concrete composites. v. 17. pp. 125 - 133. 1995.

[29] C. D. ATIS; F. OZCAN; A. KILIC; O. KARAHAN; C. BILIN; M. H. SEVERCAN. Influence of dry and wet curing conditions on compressive strength of silica fume concrete. Building and environment. v. 40. pp. 1678 - 1683. 2005.

[30] D. J. MELOLEEPSZYJ. The effect of variable curing conditions on the properties of mortars with silica fume. ACI SP-132. v. 2. pp. 1075-87. 1992.

[31] M. C, ANDRADE. Manual para diagnóstico de obras deterioradas por corrosão de armaduras. Tradução e adaptação: Antônio Carmona e Paulo Helene. São Paulo: PINI, 1992, p. 104. 